\title{
Dzintra ŠULCE
}

\section{FONËTISKO LİDZEKLUU APGUVES SPECIFIKA DAUDZVALODİBAS APSTĀKLOS}

Anotācija. 21. gadsimtā Latvija strauji ir ieklāvusies pasaules kultūras telpā, ir pieaudzis to cilvēku skaits, kas apguvuši vairākas svešvalodas, ir iepazinuši citu valsti vēsturi, kultūru un sabiedrisko dzīvi, līdz ar to ir palielinājušās iespējas dažādot savstarpējos kontaktus un paplašināt komunikāciju. Šìs tendences saglabāsies arī nākotnē, savstarpēji ietekmējot arī valodu fonētisko struktūru. Valodas saturs ir vispārcilvēcisks, bet fonētiski fonoloǵiskie līdzekli, ar kuriem to izsaka, ir nacionāli un specifiski. Veiksmīgas sazinas pamatā tiek izmantotas abas valodas izpausmes formas - gan runa, gan raksti. Pēdējos gados latviešu literārajā valodā parādās citu valodu artikulācijas un akustiskās īpatnības (visbiežāk anglu, vācu vai krievu valodas ietekmē). Tas ir vērojams gan atsevišku fonēmu izrunā, gan uzsvara lietojumā, gan teksta izrunas zināā, piem., runas intonācijā un līdzskanu palatalizācijāa, kas ir būtiska krievu un lietuviešu valodas pazīme. Fonētisko līdzeklu apguvē liela nozīme ir katra runātāja dzimtās valodas, dialekta vai izloksnes ietekmei, sagatavotības pakāpei un individuālās artikulācijas īpatnībām. Ārzemju vieslektoriem un studentiem komunikācijas procesā ir jārēkinās arī ar latviešu valodas fonētisko līdzeklu specifiku, t. i., latviešu valodai raksturīgā fonēmu artikulācija (sevišḱki garie patskani, mīkstie līdzskanni, šnāceṇi un afrikātas), pirmās zilbes uzsvars vārdos, stieptās un nestieptās zilbes intonācijas diferencēšana, stāstījuma, jautājuma un izsaukuma modalitātes izteikšana teikumā u. tml. To apguvi ietekmē ne tikai dzimtās valodas skanisko līdzeklu īpatnības, bet arī dažādi lingvistiskie un ekstralingvistiskie faktori plašākā kontekstā. Šo jautājumu apguve ir cieši saistīta ar izpratni par fonoloǵiju; tā ir valodniecības nozare, kurā galvenokārt pēta skanisko elementu funkcijas un skanu attieksmju (resp. saistǐšanās) modelus, īpašu uzmanību pievēršot tieši fonoloǵiskās sistēmas pašai mazākajai vienībai resp. fonēmai. Rakstā izteikto secinājumu pamatā ir autores praktiskā darba pieredze ne tikai Liepājas Universitātē (galvenokārt programmā "Eiropas valodu un kultūras studijas"), bet arī, strādājot ar lietuviešu studentiem Vìtauta Dižā universitātē Kauñā un ar apmainas programmas studentiem no dažādām Lietuvas augstskolām vairāku gadu garumā. Aptaujā studenti atzina, ka, ilgstoši uzturoties citā valodas vidē, piem., anglu, vācu, franču vai krievu, arī dzimtajā valodā pēc kāda laika parādās otras valodas izrunas īpatnības. Lielākoties tās ir saistītas ar vārdu krājumu resp. leksiku, taču ne mazāk svarīgi ir apzināties tās atšķirīgās un būtiskās izrunas īpatnības, kuras ir saistītas ar atseviškām fonētiskām parādībām. Apgūstot latviešu valodu, cittautieši bieži vien maina uzsvara vietu vārdos, saistot to ar savu dzimto valodu, kaut gan latviešu valodā lielākā dala vārdu ir jāizrunā ar pirmās zilbes uzsvaru. Problēmas rodas arī tajos izrunas gadījumos, kuros vārdu nozīmi diferencē tikai stieptā vai nestieptā (krītošā vai lauztā) zilbes intonācija. Citu valodu ietekmē runātāji veido t. s. hibrīdvariantus, kas izklausās pēc pusstieptās intonācijas (kaut kas pa vidu starp stiepto un nestiepto intonāciju). Divu intonāciju šksirumu ir svarīgi ievērot savstarpējā komunikācijā, lai novērstu satura pārpratumus. Citu valodu ietekmē var mainīties 
latviešu valodai raksturīgā runas melodija. İpaši tas sakāms par stāstījuma teikumu izrunu latviešu valodā ar kāpjošo melodiju nepieciešamās krītošās melodijas vietā (lielākoties anglu valodas ietekmē). Tas pats attiecas arī uz teikuma dalu saistījuma ciešuma norādi. Ja garākā teikumā nevar saklausīt ciešu vai vāju saistījumu, tas apgrūtina satura uztveri. Pēdējā laikā zūd arī jautājuma teikumiem raksturīgā intonācija latviešu valodā. Svarīgi ir apzināties teikumu modalitāti salīdzinājumā ar citām valodām. Dažādās valodās ir atškirīgs valodas ritms un runas intonācija.

Atslēgas vārdi: fonētiskie līdzeklli, to lietojuma specifika, fonēmas, vārda uzsvars, zilbes un runas intonācija, fonoloǵija.

Summary. Languages share a content common to all people; however, they differ with regard to their specific and nation-dependent phonetic means used to express it. These phonetic means grant a particular sound to each language. A phonetic system is usually based on segmental units: phonemes, syllables and syntagms. The main units of a phonetic system are closely interrelated with super-segmental or supra-segmental units, namely intonation and word stress. The present study overviews the newest tendencies in the phonetic system of the Latvian language developed due to articulatory and acoustic influence of other languages, usually English, German and Russian. The conclusions drawn in the study are based on rich teaching experience at Liepaja, Klaipeda and Vytautas Magnus Universities. It can be generalized that for successful communication both written and oral forms of language are used. When trying to integrate into any institute of higher education in Latvia, foreign teachers and students have to pay attention to the specificity of Latvian phonetic means as, for example, the stress on the first syllable. The acquisition of specific features in Latvian phonetics is influenced not only by phonetic properties of one's native language, but also by various linguistic and extra-linguistic contextual factors. A current tendency that can be observed in Latvia is a growing number of Latvians who have good communicative competence of several languages and are well acquainted with the history and culture of different countries. Their presence in the society increases the possibilities of expanding international contacts and communication and thus intensifying the aforementioned influence on the phonetic structure of the Latvian language.

Keywords: segmental and supra-segmental units, accent, word stress, intonation, phonology.

Santrauka. Bet kurios kalbos turinys yra bendras visiems žmonėms, tačiau fonetinès priemonės, kuriomis jis išreiškiamas, yra nacionalinès ir specifinès; jos suformuoja kiekvienai kalbai būdingą skambesi. Fonetinès sistemos pagrinda paprastai sudaro segmentiniai vienetai: fonemos, skiemenys, fonetiniai žodžiai ir sintagmos. Su pagrindiniais fonetinès sistemos vienetais yra glaudžiai susiję supersegmentiniai arba suprasegmentiniai vienetai - skiemens intonacija (priegaidè), žodžio kirtis ir kalbos intonacija. Straipsnyje apžvelgiamos naujausios latviu kalbos fonetiniu priemoniu sistemos tendencijos, kurios atsirado daugiausia dèl kitu kalbu artikuliaciniu ir akustiniu ypatybiu itakos (dažniausiai tai - anglu, vokiečiu ir rusu kalba). Galima pamatyti atskiru fonemy tarimo skirtumy (pvz., priebalsiu palatalizacija), taip pat priegaidžiu niveliavimo ir žodžio kirčio pakeitimo skirtumu (ypač - svetimos kilmès tikriniuose daiktavardžiuose), skiriasi ir teksto tarimo ypatybès. Šio straipsnio teiginiu ir išvadu pagrindas yra daugelio metu praktinè darbo patirtis ne tik Liepojos universitete, bet ir dirbant su lietuviu studentais Klaipèdos universitete ir Vytauto Didžiojo universitete, Kaune. Sèkmingai komunikacijai iš esmès taikomos abi kalbinès išraiškos formos - tiek kalba, tiek raštai. Patekę i latvišką aplinką, pvz., i kurią nors Latvijos aukštojo mokslo istaiga, dėstytojai iš užsienio šaliu ir studentai, atvykę pagal mainu programas, bendraudami turi atsižvelgti i latviu kalbos fonetiniu priemoniu specifika, t. y. latviu kalbai būdinga kirčiuota pirmaji skiemeni, tęstinę ir netęstinę priegaides diferencijavima, pasakojimo, klausiamoji bei šaukiamojo modalumo raišką ir pan. Ju isisavinimui jtakos turi ne tik savos gimtosios kalbos garsiniu 
priemoniu ypatybės, bet ir ivairūs lingvistiniai bei ekstralingvistiniai veiksniai platesniame kontekste. Latvijoje šiuo metu sparčiai daugejja žmoniu, kurie moka keletą užsienio kalbu, yra susipažinę su kitu valstybiu istorija, kultūra ir visuomeniniu gyvenimu, tad padaugejjo ir galimybiu paivairinti kontaktus ir išplèsti komunikacija. Šiu tendenciju išliks ir ateityje, jos darys itaką fonetinei kalbu struktūrai.

Pagrindiniai sąvokos: segmentiniai ir suprasegmentiniai vienetai, priegaidès, žodžio kirtis ir kalbos intonacija, fonologija.

\section{Ievads}

Valodai kā komunikācijas līdzeklim ir noteikts saturs un izpausmes forma. Informācijas materiālās izpausmes forma ir skañas, ko runātājs veido ar runas orgāniem, bet klausītājs uztver ar dzirdes orgāniem. Valodas saturs ir vispārcilvēcisks, bet fonētiskie līdzekli, ar kuriem to izsaka, ir nacionāli un specifiski. Fonētiskie līdzeklıi un likumi valodās ir atškirīgi, tie rada katrai valodai raksturīgo skanējumu. Valodu klausītājs saprot tāpēc, ka starp saturu un skanējumu ir izveidojušās noteiktas likumsakarības, piem., latv. bērns, liet. bernas (puisis), latv. papēdis, liet. papèdè (pēdas apakša, pamats), latv. kakts, liet. kakta (piere).

Fonētiskās sistēmas pamatu jebkurā valodā parasti veido fonēmas (to skaits mēdz būt ievērojami atškirīgs, vidēji pasaules valodās ir no 40 - 50 fonēmu), zilbes, zilbes intonācija, vārda uzsvars resp. vārda akcents un runas intonācija. Nonākot attiecīgās valodas vidē, piem., kādā Latvijas vai Lietuvas augstākajā izglītības iestādē, ārzemju vieslektoriem un studentiem komunikācijas procesā ir jārēkinās arī ar konkrētās valodas fonētisko līdzeklu specifiku. Latviešu valodai tas ir raksturīgais pirmās zilbes uzsvars, stieptās un nestieptās zilbes intonācijas diferencēšana, stāstījuma, jautājuma un izsaukuma modalitātes izteikšana teikumos u. tml. Fonētisko līdzeklu apguvi kopumā ietekmē dažādi lingvistiskie un ekstralingvistiskie faktori.

Raksta mērksis ir aplūkot jaunākās tendences latviešu valodas fonētisko līdzeklu sistēmā, kas lielākoties radušās citu valodu artikulācijas un fonētisko īpatnību ietekmēe, piem., cieto līdzskanu palatalizācija, zilbes intonācijas nivelēšanās, vārda uzsvara maina (sevišḱki - svešas cilmes īpašvārdos), teksta izrunas īpatnības ar atbilstošu runas intonāciju.

\section{Literatūras apskats}

Lingvistiskajos izdevumos līdz šim fonētisko parādību apguvei sastatījuma aspektā ir pievērsta salīdzinoši maza uzmanība (galvenokārt tiek aplūkota valodas gramatiskā sistēma un tās atškirības). Latviešu valodā šādā skatījumā ir tikai daži pētījumi, piem., jau salīdzinoši pasen izdotais darbs "Сопоставителъная грамматика русского и латышского языков" (Семенова, 1966), atsevišḱ šiem jautājumiem veltīti fragmenti ir atrodami cittautiešiem domātajās mācību grāmatās, rokasgrāmatās, rakstu krājumos, vārdnīcās u. tml. Sava praktiskā darba 
pieredzi ilgākā laika periodā Rietummičiganas universitātē (ASV, Kalamazū) no 1966. gada līdz 1993. gadam pētījumā "Latviešu valodas praktiskā fonoloǵija" (2002) ir apkopojusi L. Muižniece. Šajā darbā fonētiski fonoloǵisko līdzeklu apguvē ir norādīts uz līdzībām un atškirībām saistībā ar anglu valodu gan teorijas aprakstā, gan izvēlēto vingrinājumu atlasē. Šāda salīdzinājuma pagaidām nav ar citām valodām, kuras tradicionāli kā svešvalodas tiek lietotas Latvijas vidē. Jaunākajā lingvistiskajā literatūrā dažus jautājumus sastatījuma aspektā ir aplūkojuši J. Grigorjevs (2011), M. Brēde (2012), bet nepieciešamo terminu skaidrojumu var atrast "Valodniecības pamatterminu skaidrojošajā vārdnīcā" (2007).

\section{Pētījuma metodes un materiāli}

Atbilstoši pētījuma specifikai galvenokārt tajā ir izmantota aprakstošā un salīdzināmā metode. Būtisku vietu ieñem teorētiskās literatūras studijas un attiecīgu valodas piemēru analīze. Gatavojot rakstu, tika izveidota anketa, kuras pamatjautājumi bija saistīti ar citu valodu ietekmi dzimtās valodas (parasti latviešu valodas) apguvē un otrādi. Liepājas Universitātē "Eiropas valodu un kultūras studiju" programmas studenti atzina, ka, ilgstoši uzturoties citā valodas vidē, piem., anglu, vācu, franču, lietuviešu vai krievu, arī dzimtajā valodā pēc kāda laika parādās otras valodas izrunas īpatnības. Lielākoties tās ir saistītas ar vārdu krājumu resp. leksiku, taču ne mazāk svarīgi ir apzināties tās atškirīgās un būtiskās izrunas īpatnības, kuras ir saistītas ar atseviškām fonētiskām parādībām.

Pētījumā izteikto apgalvojumu un secinājumu pamatā ir autores praktiskā darba pieredze ne tikai Liepājas Universitātē, bet arī, strādājot ar lietuviešu studentiem Vìtauta Dižā universitātē Kauñā un ar apmainas programmas studentiem no dažādām Lietuvas augstskolām vairāku gadu garumā.

\section{Rezultāti un diskusija}

Ar fonēmu izpēti ir saistītas divas valodniecības nozares - fonētika un fonoloǵija. Fonētikas pamatā ir skanuu akustisko un fizioloǵisko īpašību izpēte, bet fonoloǵijā savukārt tiek pievērsta uzmanība fonēmu funkcijām un likumībām. Visas skaniskās vienības valodniecībā parasti iedala divās grupās:

\section{Segmentālās vienības:}

- fonēmas, piem., vārdā dziesma ir 7 burti, bet 5 fonēmas - [dz], [ie], [s], $[\mathrm{m}],[\mathrm{a}]$;

- zilbes, piem., āboli [â-buõ-li] - 3 zilbes;

- fonētiskais vārds - skaniskais komplekss, piem., labs rīts (fonētiski tas ir [laps rīc]);

- sintagma - vārds vai vārdu grupa starp divām pauzēm, piem., Vajag mācìties, // strādāt // un atpūsties. Vajag mācīties strādāt // un atpūsties. 


\section{Supersegmentālās jeb suprasegmentālās vienības:}

- zilbes intonācija, piem., plāns [plâns], [plãns]; vīle [vîle], [vĩle];

- vārda uzsvars, piem., nekas [ne•kas], labrït [lab•rît];

- runas intonācija, piem., Snieg. Snieg? Snieg!

Runas aparāts ir veidots tā, ka cilvēks spēj izrunāt daudz un dažādu skanu (pat simtiem), taču katras valodas runātāji veido samērā nelielu, atškirīgu skanu skaitu, kas veido vinu valodas fonoloǵisko pamatu. "Katrai pasaules valodai raksturīgais skaniskais inventārs ir veidojies ilgstošā, vēsturisku un ǵeogrāfisku apstāklu noteiktā procesā" (Grigorjevs, 2011, p. 80). Ikvienai valodai ir sava noteikta skanisko modelu - fonēmu - kā valodas funkcionālo pamatvienību sistēma. Fonoloǵijas likumi nosaka, kā specifisko valodu izpaust skanās un kāda ir valodas skanu sistēmas elementu organizācija, attiecības un mijiedarbība (Muižniece, 2002, p. 10). Fonēma ir valodas skanna, kas runātāja uztverē rada morfēmu un vārdu nozīmes atškirības, piem., lapa - lạba, lạpa - lāpa, masa - mazaza, mạsa - māasa, kakis - zakkis. Fonēma pati par sevi ir abstrakcija, kas runas procesā realizējas konkrētā skañā. Fonēmas konkrētā izruna mainās dažādu apstāklu dēl - gan subjektīvu (runātāja dzimums, balss augstums, dialekta īpatnības, citvalodu ietekme), gan objektīvu (blakus esošo skanu resp. fonētiskās apkaimes ietekmē), piem., līdzskanna [n] izruna mainās fonēmu [k] un [g] priekšā vārdos bungas, krunkas, vingrot, kungs, punkts. Viena un tā pati fonēma var būt akustiski atškirīga, tomēr to uztveram kā vienu un to pašu fonēmu. „Klausītājam nav grūti atšifrēt teiktā saturu neatkarīgi no runātāja individuālajām īpašībām vai runas akta apstākliem, ar nosacījumu, ka saruna notiek pazīstamā valodā. Tas nozīmē, ka dzirdes aparāts un smadzenes veic akustiskā signāla atšifrēšanu pēc shēmas, kurā noteiktām akustiskā signāla īpašībām ir liela nozīme, bet citām maza - minimāla" (Grigorjevs, 2001, p. 194). Valodas lietotājs atškirīgos fizikālos veidojumus attiecina uz vienu grupu, ja tiem ir viena un tā pati funkcija un vieta sistēmā.

Daudzvalodības apstāklos citas tautības studentiem sevišḱka uzmanība jāpievērš atsevišku segmentālo vienību apguvei, piem., latviešu valodā tā ir specifisko fonēmu - mīksto līdzskanu $k, g, g, n$, izruna, atsevišku divskanu artikulācija (sevišǩi ie un uo), šauro un plato patskanu e un $\bar{e}$ izruna, kā arī skanu savienojumi

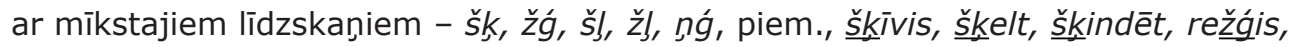
mežğît, šllukt, zižlli, kungáis.

Savukārt dzimtās valodas īpatnības ietekmē svešvalodas apguvi; tā rodas akcents, kas saglabājas, runājot citā valodā (VPSV, 2007, p. 22). Šāds akcents ir vērojams latviešu valodas cieto līdzskanuu izrunā, tos mīkstinot. Palatalizācija seviški raksturīga ir krievu un lietuviešu valodā, līdz ar to tās novēršana latviešu valodā prasa lielu uzmanību un daudz pūlu (Laua, 1997, p. 134). Savukārt anglu valodas ietekmē jūtami ir mainijjusies latviešu valodas priekšējo mēlenu [t] un [d] izruna. „Anglu valodā fonēmas [t] un [d] ir alveolāri slēdzeñi, ko artikulē, samērā platu mēles gala virsmu piespiežot pie alveolām, turpretim latviešu valodā [t] un 
[d] ir dentāli slēdzeni, ko artikulē, sasprindzinātu mēles gala ārējo malu piesitot pie augšzobiem vai augšzobu pamatnes" (Muižniece, 2002, p. 58).

Fonētisko parādību apguvei sastatījuma aspektā (jāatzīst gan - minimāli) ir pievērsta uzmanība arī atseviškos lingvistiskos pētījumos (Семенова, 1966). Darba autore akcentē, ka, piem., apgūstot krievu valodu, sevišḱka uzmanība ir jāpievērš vārda uzsvaram, jo tas ir sarežǵīts valodas skaniskās uzbūves elements, kas ir saistīts ne tikai ar fonētisko, bet arī ar gramatisko un leksisko sistēmu. Cittautu studentiem, mācoties krievu valodu, tā apguve sagādā grūtības, sevišḱki, ja uzsvaram ir fonētiski fonoloǵiska funkcija, resp., tas maina vārda nozìmi, piem., плачу, стоит, замок, духи, стрелки, мука. Valodas prakse liecina, ka minēto piemēru diferencēšana ir problemātiska arī latviešu valodas runātājiem tieši mainīgā vārda uzsvara dēll. Uzsvara apguvē ir vērojama katra studenta dzimtās valodas ietekme, sagatavotības pakāpe un individuālās artikulācijas īpatnības. Krievu valodas profesore M. N. Šutova ir raksturojusi svarīgākos uzsvara apguves metodikas jautājumus un analizējusi mūsdienīgu eksperimentu rezultātus, kas nodrošina šī jautājuma labāku izpratni un praktisko lietojumu (Шутова, 2008, p. 23). Minēto pieredzi varētu pārnemt arī citu valodu vārda uzsvara apguves nostiprināšanai.

Praktiskā darba pieredze rāda, ka, apgūstot latviešu valodu, cittautieši (sevišksi krievu un lietuviešu studenti), maina uzsvara vietu vārdos, saistot to ar savu dzimto valodu, kurā ir brīvais vārda uzsvars, piem., vārdos, kurus latviešu valodā jāizrunā ar pirmās zilbes uzsvaru: Sarajeva, Šopēns, Šumahers, Musorgskis, Karzajs.

Valodas prakses piemēri liecina, ka problēmas latviešu valodas apguvē rodas homogrāfu - heterotonu izrunas gadījumos, kuros vārdu nozīmi diferencē tikai stieptā vai nestieptā (krītošā vai lauztā) zilbes intonācija (Šulce, 2007, p. 276). Citu valodu ietekmē runātāji veido t. s. hibrīdvariantus, kas izklausās pēc pusstieptās intonācijas (kaut kas pa vidu starp stiepto un nestiepto intonāciju). Divu intonāciju šksirumu ir svarīgi ievērot savstarpējā komunikācijā, lai novērstu satura pārpratumus, piem.:

- Cenas par apkuri ziemas periodā klūst arvien augstākas un augstākas (izrunā nepareizi ar stiepto intonāciju).

- Tiks izdoti dzejnieka Ojāra Vācieša kopotie raksti vairākos sējumos (izrunā nepareizi ar stiepto intonāciju).

- Mana māsa grib_griezt maizíti (izrunā nepareizi ar stiepto intonāciju).

- Manikīre pañēma nagu vīlīti (izrunā nepareizi ar nestiepto intonāciju).

Citu valodu ietekmē var mainīties latviešu valodai raksturīgā runas melodija. Savstarpējā sazin̄ā izteikumi tiek veidoti tā, lai pēc iespējas saniegtu labāku prognozēto rezultātu. Tas ir atkarīgs no runas situācijas un sarunas partnera (-iem). "Pētījumi liecina, ka informācija klausītājam galvenokārt tiek nodota ar intonācijas un sintaktiskās struktūras savstarpējās mijiedarbības palīdzību" (Brēde, 2012, p. 13). Īpaši tas sakāms par stāstījuma teikumu izrunu latviešu valodā ar kāpjošo melodiju nepieciešamās krītošās melodijas vietā (lielākoties anglu valodas ietekmē). Tas pats attiecas arī uz teikuma dalu saistījuma ciešuma norādi. 
Ja garākā teikumā nevar saklausīt ciešu vai vāju saistījumu, tas apgrūtina satura uztveri. Vēl lielākas grūtības rodas šādas runas atspogulošanā rakstu formā, jo nav iespējams noteikt teikumu robežas. Pēdējā laikā zūd arī jautājuma teikumiem raksturīgā intonācija latviešu valodā. Svarīgi ir apzināties teikumu modalitāti salīdzinājumā ar citām valodām. Dažādās valodās ir atškirīgs valodas ritms un runas intonācija. Tas lautu izvairīties no svešām intonācijām, kā arī pareizi apgūt citas valodas intonatīvo sistēmu. Valodas prakse liecina, ka latvieši pārspīlē, atdarinot citu valodu runas intonācijas, līdz ar to pieškirot latviešu valodai nedabisku skanējumu, kas traucē un apgrūtina satura uztveri (Strautina, Šulce, 2009, p. 46).

\section{Secinājumi}

1. Pēdējos gados latviešu literārajā valodā parādās citu valodu artikulācijas un akustiskās īpatnības (visbiežāk anglu, vācu un krievu valodas ietekmē) gan atsevišksu fonēmu izrunā, gan uzsvara lietojumā, gan teksta izrunas ziñā, piem., runas intonācijā un līdzskanuu palatalizācijā.

2. Fonētisko līdzeklu apguvē ir vērojama katra runātāja dzimtās valodas vai izloksnes ietekme, sagatavotības pakāpe un individuālās artikulācijas īpatnības. To apguvi ietekmē arī dažādi lingvistiskie un ekstralingvistiskie faktori.

3. İpaša uzmanība ir jāpievērš latviešu valodai specifisko mīksto līdzskanuu $k$, ǵ, n, l izrunai, divskanuu artikulācijai (seviškji ie un uo), šauro un plato patskanuu e un ē izrunai, kā arī skanu savienojumiem ar mīkstajiem līdzskanjiem, piem., šskìisis, šḱselt, škindēt, režǵis, mežǵît, šlūkt, zižli, kungáis.

4. Fonētisko parādību apguve ir svarīga sastatījuma aspektā, piem., apgūstot valodas ar brīvo vai saistīto vārda uzsvaru. Cittautu studentiem tā apguve sagādā grūtības gadījumos, ja uzsvaram ir fonētiski fonoloǵiska funkcija, resp., tas maina vārda nozīmi, piem., krievu valodā vārdos плачy, стоит, замок, духи, стрелки, мука.

5. Lai nerastos satura pārpratumi, savstarpējā komunikācijā ir svarīgi apzināties stieptās un nestieptās intonācijas šksirumu latviešu valodā tajos gadījumos, kuros vārdu nozīmi diferencē tikai intonācija, piem., Raina kopotie raksti ir vairākos sējumos. Šogad samazinājās graudaugu sējumi.

6. Citu valodu ietekmē ir mainījusies latviešu valodai raksturīgā runas melodija. Tas ir saistīts ar stāstījuma teikumu izrunu latviešu valodā, kuros nepieciešamās krītošās melodijas vietā ir dzirdama kāpjošā melodija. Tas pats attiecas arī uz teikuma dalu saistījuma ciešuma norādi. Atkāpes intonatīvajā veidojumā ir vērojamas arī teikumos ar jautājuma modalitāti.

7. Latvijā strauji ir pieaudzis to cilvēku skaits, kas apguvuši vairākas svešvalodas, ir iepazinuši citu valsti vēsturi, kultūru un sabiedrisko dzīvi, līdz ar to ir palielinājušās iespējas dažādot savstarpējos kontaktus un paplašināt komunikāciju. Šìs tendences saglabāsies arī nākotnē, savstarpēji ietekmējot valodu fonētisko struktūru. 


\section{Literatūra}

Brēde, M. (2012). Ieskats publiskā intonācijas stila raksturojumā. Literārā valoda (standartvaloda) vēsturiskā, normatīvā un sociolingvistiskā skatījumā. Akadēmika Jāña Endzelīna 139. Dzimšanas dienas atceres starptautiskās zinātniskās konferences materiāli (pp. 13-14). Rīga: LU Latviešu valodas institūts.

Grigorjevs, J. (2001). Dažādu runātāju (sieviešu un vīriešu) izrunāto patskanuu akustisko ideālformu noteikšana. Linguistica Lettica, 3, 194-215. Rīga: Latviešu valodas institūts.

Grigorjevs, J. (2011). Kopīgais un atšksirīgais fonētisko parādību izpratnē Latvijā un pasaulē. Valodas prakse: vērojumi un ieteikumi, 6, 80-97. Rīga: Latviešu valodas aǵentūra.

Laua, A. (1997). Latviešu literārās valodas fonētika. Rīga: Zvaigzne ABC.

Muižniece, L. (2002). Latviešu valodas praktiskā fonoloǵija. Rīga: Rasa ABC.

Strautina, V., \& Šulce, Dz. (2009). Latviešu valodas pareizruna un pareizrakstība. Rīga: RaKa.

Šulce, Dz. (2007). Problēmjautājumi pareizrunā. Vārds un tā pētīšanas aspekti, 11, 274-281. Liepāja: LiePA.

VPSV (2007). Valodniecības pamatterminu skaidrojošā vārdnīca. Rīga: Latviešu valodas institūts.

Семенова, М. Ф. (1966). Сопоставителъная грамматика русского и латышского языков. Рига: Звайгзне.

Шутова, М. Н. (2008). Методика обучения иностранных студентов русскому ударению как средству общения. Русский язык за рубежом. Учебно методический иллюстрированный журнал, 6 (211), 18-23.

\begin{tabular}{|c|c|}
\hline $\begin{array}{r}\text { Dzintra ŠULCE } \\
\text { PhD in Philology, Assoc. Professor of } \\
\text { the Latvian Language, Expert in the } \\
\text { field of Linguistics }\end{array}$ & $\begin{array}{l}\text { Dzintra ŠULCE } \\
\text { Filologijos mokslo daktarè, latvių } \\
\text { kalbos docentė, kalbotyros krypties } \\
\text { ekspertė }\end{array}$ \\
\hline $\begin{array}{r}\text { Fields of scientific interests: Latvian } \\
\text { Language phonetics, comparative Baltic } \\
\text { studies, language culture }\end{array}$ & $\begin{array}{l}\text { Moksliniu interesu sritys: latviu kalbos } \\
\text { fonetika, lyginamoji baltistika, kalbos } \\
\text { kultūra }\end{array}$ \\
\hline $\begin{array}{r}\text { Faculty of Humanities, } \\
\text { Liepaja University }\end{array}$ & $\begin{array}{l}\text { Liepojos universitetas, } \\
\text { Humanitariniu moksly fakultetas }\end{array}$ \\
\hline $\begin{array}{r}\text { Rojas str. 3-43, LV-3407, Liepaja } \\
\text { Latvia }\end{array}$ & $\begin{array}{l}\text { Rojas g. 3-43, LV-3407, Liepoja } \\
\text { Latvija }\end{array}$ \\
\hline dz.sulce@tvnet.lv & dz.sulce@tvnet.Iv \\
\hline
\end{tabular}

